\title{
Why do most Gitano/Romani students not complete compulsory secondary education in Spain? Uncovering the view of the educational community using concept mapping
}

\author{
Arturo Álvarez ${ }^{1 a}$, Iván Parra ${ }^{1}$, and Juan F. Gamella ${ }^{1}$ \\ ${ }^{1}$ Department of Social Anthropology, Faculty of Philosophy and Arts, University of Granada, \\ Granada, 18071, Spain
}

\begin{abstract}
This paper describes the results of research that used Concept Mapping to study the causes of the high rates of school failure among the students of the Gitano or Spanish Romani minority. A sample of 52 members of a school community-pupils, families and teachersparticipated in the research. Data were collected in focus groups. Generated ideas were sorted and rated by participants. A multidimensional scaling of sorted data resulted in a map of points. A cluster analysis with the points' coordinates was run. The results uncovered a model of six clusters: ethnic differences, families, adolescent risk behaviours, students' attitudes and values, curriculum gap, and finally effects of compensatory education and attention to diversity programmes. The relationships among the clusters point to three sources of concern: cultural and gender issues within the family setting that encourage girls to drop out of school; lack of motivation and educational orientation of the students; and structural problems of the educational system that contribute to maintain the educational gap between minority and majority students.
\end{abstract}

\section{Introduction}

The poverty, discrimination, and vulnerability that disproportionately affect most Romani groups have become a major concern for the European Union. One of the key elements in this situation is the low level of education attainment and training of these populations [6]. Improvement in education is one of the basic objectives of policy programmes that seek to ameliorate these disadvantages [5].

In Spain, the autochthonous Romani people or Gitanos still suffer from a considerable educational gap with respect to the rest of the population, although the level of formal education among them has increased considerably in the past three decades. Since 1986,

\footnotetext{
a Corresponding author: aalvarez@ugr.es
} 
Romani children were integrated into Spanish public schools such that, within the space of one generation, the schooling of Gitano children in primary education was accomplished. However, a new problem appeared: the abandonment of education before completing high school [7].

In this paper, we present the results of an investigation that employed Concept Mapping (CM) -a mixed methods approach [10] - to diagnose the causes of school failure, as they were perceived by the educational community, at a middle school centre with a high number of Romani students. We believe that teachers, students, and their families are the best placed to identify the causes of the problem. What experience does each one of these groups have with the problem at hand? Which issues do each one of them consider as the most important causes of school failure? What notions are encapsulated in each of these issues? Which issues are the participants in agreement about? Which ones do they disagree about, and why?

\section{Methods}

$\mathrm{CM}$ is structured in four stages. It begins with a first collective session wherein the participants take part in brainstorming. This is followed by a second session in which they individually sort and rate the ideas collected in the first session. Afterwards, the researchers register the data of each participant in a one-mode similarity matrix. These individual matrices are added together. The aggregate matrix is used to conduct a two-dimensional nonmetric multidimensional scaling (MDS). The result is a point map. The points represent statements and the distance between them indicates their proximity. In the next stage, a hierarchical cluster analysis (HCA) is conducted using the MDS point coordinates as data. In a fourth session, following these procedures, the participants help interpret and name the elements of the conceptual map and decide how to use it.

\subsection{Area of study and participants}

The investigation was conducted at a high school in a locality in the province of Granada, Spain, where we have developed long-term fieldwork. The locality was selected because it had one of the largest concentrations (30\%) of Romani populations in the entire region and even Spain. Notably, the local minority population was quite segregated regarding housing, work, and even marriage [6 and 9].

At the time of study, the chosen school had 750 students, 264 of whom were enrolled in compulsory secondary education (ESO). In 2014, the percentage of students of Gitano ethnicity enrolled in the first year of ESO was $55.7 \%$. In contrast, $39.53 \%$ were enrolled in the second year, the third year had only $10.5 \%$, and none were enrolled in the fourth year. The percentage of Gitano students in studies beyond this was $0.3 \%$.

We sought to represent within our sample all the perspectives about education and school failure available at the centre. The management team, counsellors, mediators, and members of the parents' association were all called upon to help us select the participants. Twenty-seven people participated in the brainstorming phase. Another 22 people from the first phase, plus 30 other people, took part in the sorting and rating phase (see Table 1). 
Table 1. Participants.

\begin{tabular}{lll}
\hline & Brainstorming & Sorting \& rating \\
\hline $\begin{array}{l}\text { Teachers and counsellors } \\
\text { Students }\end{array}$ & $7(0)$ & $15(0)$ \\
$\quad$ Compensatory education (1 $1^{\text {st }}$ year of ESO) & $7(6)$ & $6(5)$ \\
$\quad$ Attention to diversity ( $3^{\text {rd }}$ year of ESO) & & $15(2)$ \\
Family members & $13(7)$ & $16(9)$ \\
\hline Total & $27(13)$ & $52(16)$ \\
\hline
\end{tabular}

\subsection{Focus question}

The conceptual map is created using participants' responses to a question that defines the focus or domain of conceptualization. It tries to capture all facets of the phenomenon studied-school failure in this case. We developed the focus question with the assistance of the teaching team during the preparation stage. The question was: 'Why do some students obtain the secondary school certificate and others do not?' [¿Por qué hay alumnos/as que consiguen el título de secundaria y otros/as no?].

\subsection{Brainstorming, pile sorting and rating}

The brainstorming session was conducted in separate groups: teachers and counsellors, students, and family members. Each group was asked the focus question. This produced a set of 279 responses. Finally the responses were reduced to 50, which, in the encoders' opinion, represented all the ideas expressed during the brainstorming sessions. This number of responses proved to be manageable for all of the participants during pile sorting. In the second session, the participants were asked to sort the ideas in piles and, when possible, name each of them. Lastly, they were asked to rate how much they agreed with each of the ideas on a Likert-type scale of 1 to 5 .

\subsection{Data Analysis}

Data from each individual sorting exercise were transformed into a 50x50 one-mode similarity matrix using the UCINET 6 program. The matrices were combined. In the aggregate matrix, each cell represented the number of participants (a maximum of 52) that together sorted the two ideas that appeared in the corresponding rows and columns.

Following this, a two-dimensional non-metric multidimensional scaling (Torsca initial configuration) of the aggregate matrix was undertaken using the UCINET 6 program. The result was a point map, wherein each point corresponded to each of the ideas. The coordinate points of the MDS were used to run a hierarchical cluster analysis using Ward's method in SPSS.22. During the final joint session involving all of the participants, the results of the analysis were presented in an attempt to try to make sense of them and jointly decide on the research results.

\section{Results}

Table 2 shows the 50 ideas grouped into clusters, along with the degree of agreement about the responses that was shown by the participants. Figure 1 shows the MDS plot of the 50 
statements based on the pile sorting data of all participants. Kruskal's stress value on the map was 0.191. This is below 0.366, which Sturrock \& Rocha [13] consider as an acceptable cut-off value in a two-dimensional MDS for 50 objects. The map also displays the resulting groupings of the hierarchical cluster analysis of the 50 ideas.

Each of these clusters brings together various ideas regarding an obstacle that teenagers encounter to finishing secondary education. C\#1 'Ethnic differences' refers to a series of school-related problems that specifically affect Romani youth. Among them, we can highlight the institution of teen marriage for girls, which is still very frequent in the local Gitano community. Ethnic, social, and economic segregation, including conflicts between non-Gitanos and Gitanos, also can be associated with school failure for the latter group.

\begin{tabular}{|c|c|c|}
\hline \multirow[t]{3}{*}{ Items per cluster } & \multicolumn{2}{|c|}{ Degree of agreement } \\
\hline & Ave & Standard \\
\hline & rage & deviation \\
\hline C\#1: Ethnic differences & 3.20 & 1.35 \\
\hline 11 ...Gitano girls marry very young. & 4.08 & 1.16 \\
\hline 7 ...Payos (non-Gitanos) go one way and Gitanos go the other. & 3.39 & 1.39 \\
\hline 25 ...the Gitano 'pañuelo' custom (virginity ritual) triggers girls to drop out of school. & 3.29 & 1.40 \\
\hline 48 ...the problem is that there are many 'ethnic'b children and their parents don't take care & & \\
\hline of them. & 3.14 & 1.31 \\
\hline $23 \ldots$... Gitanos and Payos (non-Gitanos) bother one another and sometimes fight. & 3.12 & 1.34 \\
\hline 15 ...the region's social and economic context encourages failure. & 2.92 & 1.23 \\
\hline 20 ...they tell Gitano children who pass their exams that they're 'apayados' (acting like & & \\
\hline Payos). & 2.86 & 1.34 \\
\hline 29 ...they associate academic success with a social class or ethnic group that is not theirs. & 2.82 & 1.24 \\
\hline C\#2: Families & 3.14 & 1.36 \\
\hline 42 ...some families set a bad example for their children. & 3.43 & 1.39 \\
\hline 4 ...children don't receive support at home. & 3.35 & 1.21 \\
\hline 21 ...when parents leave for seasonal work the older sisters must care for the younger & & \\
\hline children. & 3.27 & 1.33 \\
\hline 49 ...some parents think that their daughters don't need to study to become homemakers. & 3.26 & 1.36 \\
\hline 12 ...parents don't become involved in their children's education in terms of discipline, & & \\
\hline help, materials, tutoring, etc. & 3.22 & 1.33 \\
\hline 27 ...parents don't have the educational training necessary to help their children. & 3.00 & 1.30 \\
\hline 19 ...parents can't make children study if children don't want to. & 2.80 & 1.54 \\
\hline $24 \ldots$ their families are badly off financially. & 2.80 & 1.31 \\
\hline C\#3: Adolescent risk behaviours & 3.72 & 1.22 \\
\hline 18 ...drug and alcohol experiences lead children astray. & 4.08 & 1.02 \\
\hline 37 ...they spend all day on their cell phones and playing video games. & 3.76 & 1.29 \\
\hline 26 ...some girls get pregnant and drop out. & 3.69 & 1.24 \\
\hline 41 ... some children get side-tracked by couple relationships. & 3.61 & 1.11 \\
\hline 17 ... depends on the person, on his/her personality and demeanour. & 3.45 & 1.38 \\
\hline C\#4: Students' attitudes and values & 3.39 & 1.27 \\
\hline 34 ...they are influenced by friends and bad company. & 4.02 & 0.91 \\
\hline 2 ...they lack study habits. & 3.82 & 1.14 \\
\hline 36 ...their goals don't include schooling. & 3.69 & 1.05 \\
\hline 13 ...they lack motivation. & 3.67 & 1.24 \\
\hline 3 ... since some assume they're going to fail, they don't try to pass. & 3.55 & 1.22 \\
\hline 32 ...they want to leave school in order to work and make money. & 3.51 & 1.25 \\
\hline 14 ...they think that even if they pass they won't be able to get a job later on. & 3.43 & 1.27 \\
\hline 44 ...they lack self-esteem. & 3.41 & 1.13 \\
\hline 43 ...they prefer to spend time in the street and have more freedom. & 3.39 & 1.47 \\
\hline 31 ...they don't see the point of studying. & 3.33 & 1.23 \\
\hline 45 ...they don't see schooling as a means to a livelihood. & 3.31 & 1.17 \\
\hline 47 ...they think they can make a living without having to study. & 3.31 & 1.10 \\
\hline 35 ...they don't value hard work. & 3.08 & 1.43 \\
\hline 28 ...they don't receive anything in exchange for the effort it takes to study. & 2.71 & 1.33 \\
\hline
\end{tabular}

\footnotetext{
b 'Ethnic children' (niños de etnia) is the expression used by the educational administration to refer to Gitano students. This term is now used by most of the members of the educational community.
} 
30 ...they're too proud and that's not okay.

33 ...they pass their courses without attaining the basic skills, and each year it's harder for them to keep up.

6 ... when they fall behind, they get bored.

46 ...children have a hard time adjusting to the changes in academic levels and many can't handle it.

39 ...when they fall behind, they get embarrassed around the others.

8 ...children that fall behind hold back everyone else.

1 ...the schedule is bad; you have to get up early.

\section{C\#6: Compensatory education and attention to diversity programmes}

5 ...some teachers don't know how to connect with the children. bad.

40 ...even though teachers try to avoid it, racism exists, and it makes some children feel

16 ...students at the school are differentiated into two groups: compensatory students and the rest.

$38 \ldots$... some teachers are impatient with certain students and students act badly towards them.

22 ...there aren't enough teachers to address the needs of the diverse students.

10 ...some teachers' teaching methods discourage the students.

9 ...in areas of integration, there are conflicts between diverse students and the rest.

50 ...the curriculum (goals, content, methodology, and assessment) isn't adequate to the

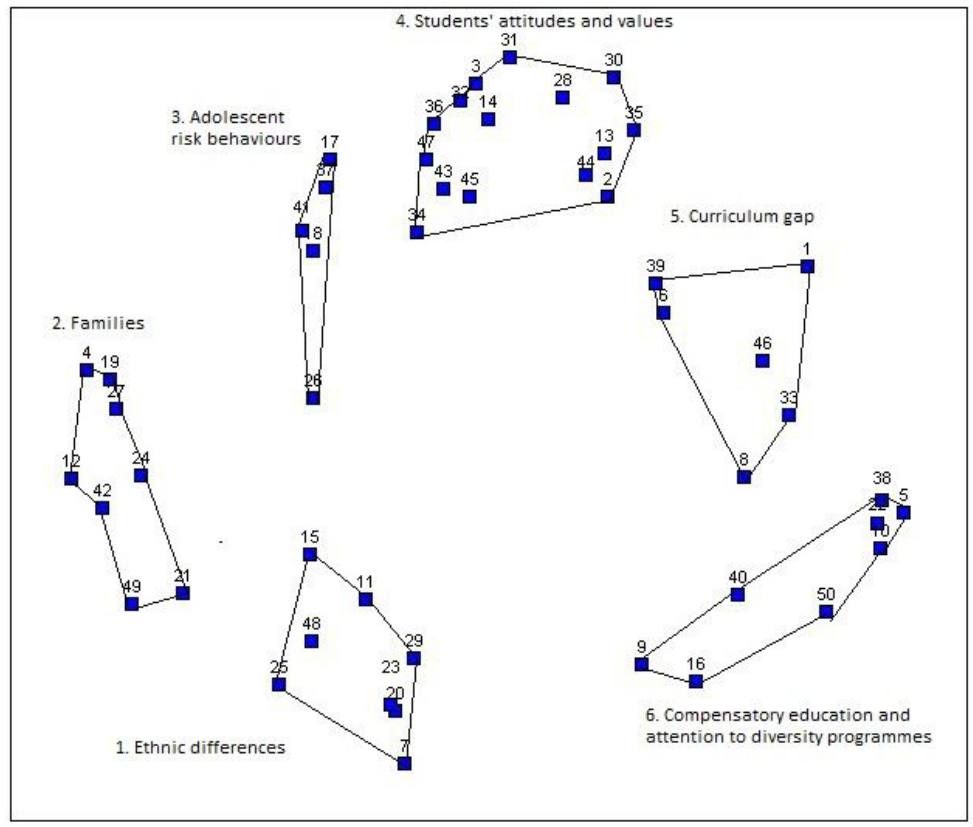

Fig. 1. Multidimensional scaling of the 50 statements grouped in clusters

C\#2 'Families' denotes a set of problems that are believed to be faced disproportionally by Gitano students, although not exclusively: dysfunctional families that are a bad influence on their children; families that don't support their children's education; families that are barely in contact with the school and teachers and do not support their work; and families that place low value on education, especially girls' education. Notably, such families face economic hardships and prefer that their children start working as soon as possible rather than continue to attend school.

C\#3 'Adolescent risk behaviours' is the cluster that has the lowest number of responses, but the highest consensus in terms of ratings. It represents teenage behavioural problems 
that often have a negative repercussion on studies: alcohol and drug use, couple relationships, undesired pregnancies, excessive use of cell phones and video games, etc. All these factors are believed to be related to age and individual personalities.

C\#4 'Students' attitudes and values' encompasses 15 responses that refer to the attitudes that students who do not graduate from secondary school have towards their studies and future job prospects: they lack motivation and self-esteem; they do not value the effort; they do not see the use of studying and do not think it will help them find a job; they prefer the pleasure they get from being with friends on the streets, not having responsibilities and being able to make some money doing low-skilled jobs. These attitudes and values derive mostly from peer groups.

C\#5 'The curriculum gap' includes those responses that point to the gap in the curricular level held by students doing poorly in their studies and the level they should be at based on their age. These ideas refer especially to Gitano students in compensatory programmes and students in diversity programmes. The curriculum gap experienced by the students is viewed as an obstacle to normal class performance for the rest of the students.

Lastly, C\#6 'Compensatory education and attention to diversity programmes' reflects the difficulties involved in applying compensatory programmes to Romani students and/or students at risk of social exclusion and diversity programmes to students with special educational needs. The prevalent view is that more and better trained teachers are needed, and that educational methods and curriculum must be culturally and socially adapted to the students' needs.

\section{Conclusion}

The relationships among the clusters point to three sources of problems for which an intervention would be most important. One encompasses cultural and gender issues within the family setting that encourage school dropout, especially among girls [11]. A second cluster concerns the motivation and educational orientation of the students within the opportunity environment of the region. And a third cluster that points to the need to address problems that cause the curricular gap and the segregation of minority students [3 and 11]. The separation of $\mathrm{C \# 1}$ and $\mathrm{C \# 2}$ with respect to $\mathrm{C \# 3}, \mathrm{C \# 4}, \mathrm{C \# 5}$, and $\mathrm{C \# 6}$ indicates two social fields of action, the families and the school, and demonstrates the need to improve the relationships between both social settings [1,2, 4 and 8].

A review of the relevant literature on school success and failure for Romani adolescents has allowed us to verify that the vision provided by $\mathrm{CM}$ integrates most of the factors revealed by expert studies. Moreover, we think that $\mathrm{CM}$ points to new research topics on school failure among Romani students that need to be studied in more depth: teenage marriage, youth behavioural problems, the side-effects of compensatory and diversity educational programmes, and the importance of social networks in the students' educational processes.

\section{Acknowledgements}

This research was supported by Grant Number P11-SEJ-8286 - Proyectos de investigación de Excelencia of the Regional Ministry of Economy, Innovation, Science, and Employment (Consejería de Economía, Innovación, Ciencia y Empleo de la Junta de Andalucía). 


\section{References}

1. Abajo, J. E., \& Carrasco, S., Experiencias y trayectorias de éxito escolar de gitanas y gitanos en España. [Experiences and trajectories of educational success among Gypsies in Spain]. Madrid: CIDE (Ministerio de Educación, Política Social y Deporte) / Instituto de la Mujer (Ministerio de Igualdad) (2004)

2. Bereményi, B.-Á., Claro hijo, vaya a la escuela y si se aburre lo sacamos. Relaciones y experiencias de los gitanos de Badalona y los rom de Bogotá con la educación escolar. ["Sure son, go to school and we'll take you out if you get bored": Relationships and experiences of the Gypsies of Badalona and the Roma of Bogota with school education]. Universitat Autònoma de Barcelona (2007)

3. Bhopal, K., "This is a school, it's not a site": teachers' attitudes towards Gypsy and Traveller pupils in schools in England, UK. British Educational Research Journal, 37(3), 465-483 (2011)

4. Derrington, C., \& Kendall, S., Gypsy traveller students in secondary schools. Culture, identity and achievement. Stoke on Trent: Trenthan Books (2004)

5. European Commission., An EU framework for national Roma integration strategies up to 2020. Brussels (2011)

6. FRA (European Union Agency for Fundamental Rights)., Roma survey - Data in focus education: The situation of Roma in 11 EU Member States. Luxembourg: Publications Office of the European Union (2014)

7. Gamella, J. F., La población gitana en Andalucía. Un estudio exploratorio de sus condiciones de vida. [The Gypsy population in Andalusia: An exploratory study of their livelihood conditions]. Sevilla: Consejería de Trabajo y Asuntos Sociales, Junta de Andalucía (1996)

8. Gamella, J. F., Historias de éxito. Modelos para reducir el abandono escolar de la adolescencia gitana. [Success stories: Models for reducing the dropout rate among Gypsy adolescents]. Madrid: Ministerio de Educación. Retrieved from http://www.educatolerancia.com/pdf/Historias de exito_ Modelos para reducir el abandono escolar de la adolescencia gitana.pdf (2011)

9. Gamella, J. F., Martín Carrasco-Muñoz, E., \& Quesada Garrido, A., New methodological approaches in the anthropological demography of Romani groups. An example from the study of the evolution of the infant and child mortality of the Gitanos or Calé of Spain (1871-2007). Sociologia, Revista Da Faculdade de Letras Da Universidade Do Porto, Número temático - Ciganos na Península Ibérica e Brasil: estudos e políticas sociais, 175-204 (2014)

10. Kane, M., \& Trochim, W. M. K., Concept mapping for planning and evaluation. Thousand Oaks, California: Sage (2007)

11. Levinson, M. P., "What's the plan?" "What plan?" Changing aspirations among Gypsy youngsters, and implications for future cultural identities and group membership. British Journal of Sociology of Education, 1-21, doi:10.1080/01425692.2014.897217 (2014)

12. Levinson, M. P., \& Sparkes, A. C., Conflicting value systems: Gypsy females and the home-school interface. Research Papers in Education, 21(1), 79-97 (2014)

13. Sturrock, K., \& Rocha, J., A multidimensional scaling stress evaluation table. Field Methods, 12(1), 49-60 (2000) 